\title{
PROGIMNAZIJOS VADOVO LYDERYSTE் MOKYKLOS VEIKLOS VALDYME
}

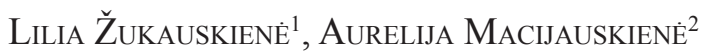 \\ Klaipedos universitetas (Lietuva)
}

\begin{abstract}
ANOTACIJA
Straipsnyje nagrinejjama progimnazijos vadovo lyderyste šio tipo mokyklos veiklos valdyme. Pristatomi interviu su progimnazijų vadovais rezultatai. Tyrimas atliktas, taikant fenomenologinès strategijos metodą, kuris padeda geriau suprasti vadovo lyderystę, siekiant progimnazijos veiklos valdymo praktikos veiksmingumo. Kokybiniame tyrime dalyvavo penki Lietuvos Vakarų regiono progimnazijų (Klaipėda, Šilute, Kretinga, Tauragè) vadovai. Atskleisti šie esminiai lyderystès veiklos valdyme požymiai: vadovo atsakomybè ir kitų bendruomenės narių telkimas veiklos valdymui; bendruomenès narių įtraukimas ị veiklos valdymą reiškiasi diskusijų, darbo grupių ir kitomis formomis; vadovų skatinami bendruomenès nariai įsitraukia ị valdymo sambürius ir veiklą; vadovai priima mokytojų iniciatyvas, dalijasi su jais lyderystės patirtimi, skatina mokytojų lyderystės ịsitvirtinimą progimnazijoje. Vadovų lyderystė reiškiasi nuolatiniu pažangos ir pasiekimų stebẻjimu bei vertinimu, veiklos tikslų ir rezultatų analize bei refleksija. Kaip veiksmingos išskirtos šios progimnazijos vadovų veiklos valdymo priemonės: nuolatinio įstaigos įsivertinimo ir ugdymo proceso dalyvių nuomonès tyrimų organizavimas, darbo bei ugdymo(si) sąlygų gerinimas, veiklos valdymo tobulinimas, mokytojų savišvieta, projektinè veikla, inovacijų diegimas.
\end{abstract}

PAGRINIAI ŽODŽIAI: progimnazija, vadovas, lyderystès kompetencija, veiklos valdymas.

JEL KLASIFIKACIJA: I12, I21; I31.

DOI: http://dx.doi.org/10.15181/rfds.v32i3.2153

Ivadas

Šiuolaikiniame pasaulyje vis dažniau pabrěžiama lyderystès įtaka institucijos veiklai ar individo sėkmei, ypač akcentuojamas švietimo institucijų kontekstas, nes mokyklos veiklos veiksmingumas didina visų jos narių mokymosi sèkmės galimybes (Marzano ir kt., 2011). Lyderystė tapo prioritetine švietimo politikos sritimi, tad ir Lietuvoje vis daugiau kalbama apie švietimo sistemos tobulinimą, pertvarkymą, Lietuvai įžengus ị naują raidos etapą, siekiant ịsitvirtinti tarptautinejje erdveje, mokantis bendradarbiauti ir konkuruoti globaliame pasaulyje. Vienas XXI amžiaus Lietuvos švietimo sistemos pokyčių - įteisinta nauja mokyklų tinklo struktūra ir numatytas naujas mokyklos tipas - progimnazija, kurios paskirtis - vykdyti pagrindinio ugdymo programą (arba jos dali) ir parengti mokinius (1-8 klasès) tolesniam mokymuisi (Lietuvos Respublikos švietimo ịstatymas, 2011, 41 str., 2 d. Teisès akto redakcija įsigaliojo 2020-01-01). Iš šio mokyklų tinklo pertvarkos tikètasi, kad sutelkus vaikus pagal amžiaus grupes, progimnazijoje pavyks ne tik sudaryti palankesnes sąlygas vaikų ugdymui(-si), bet ir kur kas veiksmingiau panaudoti valstybės bei savivaldybiu lëšas. Progimnazija tapo tarsi tarpine grandimi tarp pradinès mokyklos ir gimnazijos, ją baigęs asmuo gali laisvai rinktis mokslus gimnazijoje ar profesinio mokymo įstaigoje (Progimnazijų ir pagrindinių mokyklų paskirtis ir vieta bendrojo ugdymo sistemoje, 2016).

1 Lilia Žukauskienè - profesorè, daktarè, Klaipèdos universiteto Socialinių ir humanitarinių mokslų fakulteto Pedagogikos katedra Moksliniai interesai: edukologija ir jos istorija, socialinè edukologija, suaugusiųų mokymasis, lyderystė ugdymo institucijoje El. paštas: lilia.zukauskiene@gmail.com

2 Aurelija Macijauskienè - Klaipėdos licèjaus mokytoja, Klaipėdos universiteto Socialinių ir humanitarinių mokslų fakulteto Pedagogikos katedros lektoré

Moksliniai interesai: edukologija, lyderystė mokykloje, alfa kartos vaikai ir jų ugdymo(-si) ypatumai

El. paštas: aurelija.macijauskiene@gmail.com 
2015 metais Nacionalinè mokyklų vertinimo agentūra (NMVA) paskelbė mokyklų veiklos kokybės išorinio vertinimo duomenis (2015), kurie atskleide, kad progimnazijos veiklos kokybè, sukuriama pridėtinè verte ir mokinių mokymosi pasiekimai, lyginant su kitais mokyklos tipais (pagrindinės mokyklos), yra vieni geriausių, atotrūkis tarp šių mokyklų siejamas su socialine, ekonomine ir kultūrine mokinių aplinka (Bendrojo ugdymo mokyklų veiklos kokybè, NMVA metinis pranešimas, 2015).

Šiandien visuomenè ir mokykla ieško kuo efektyvesnių būdų, kaip vykdyti visus būtinus švietimo sistemos pokyčius, kartu auga savarankiškų bei edukacinėje veikloje save kūrybiškai atskleidžiančių asmenybiu poreikis (Kim ir kt., 2017; Navaitienė ir kt., 2017; Saleem ir kt., 2020). Švietimo institucijų pokyčiu atžvilgiu lyderyste pripažįstama kaip reikšmingas veiksnys (Sotrey, 2016; Saleem ir kt., 2020), skatinantis kurti aplinką, kurioje pedagogai dirbtų efektyviau, ugdytiniai noriai mokytųsi ir siektų aukštesnių rezultatų (Haynes ir kt., 2014).

Lyderystė skirtingiems žmonėms skirtinguose kontekstuose reiškia skirtingus dalykus, tačiau ji iš esmès suprantama kaip įtakos procesas, keičiantis individų ar jų grupių elgseną (Yukl, 2012), ypač siekiant bendrų tikslų (Northouse, 2016; Cibulskas, Židžiūnaitè, 2012), švietimo institucijoje ji pasižymi įvairialypiškumu ir kompleksiškumu (Sower, 2018). Lyderiai mokykloje yra žmonès, kurie prisiima atsakomybę ne tik mokykloje, bet ir už jos ribų (Wenner ir kt., 2017: 7). Lyderis siekia transformuoti darbuotojų lūkesčius, keisti jų požiūrị, poreikius derindamas su organizacijos tikslais, aiškiai pristato numatomų tikslų ígyvendinimo būdus, skatina dirbti komandoje (Skarbalienè, 2015: 143).

Mokslininkai (Saleem ir kt., 2020) pastebi, kad kurị laiką didesnis dėmesys buvo skiriamas mokyklos vadovo lyderystei, bet bendroje švietimo ịstaigos aplinkoje svarbi tiek formalaus mokyklos vadovo, tiek ir mokytojų lyderystė. Pasak E. Leffler (2019), lyderio vietą mokykloje gali užimti ne tik mokyklos vadovas, bet ir mokytojas.

Sparčiai besikeičianti mokykla ir šiuolaikinè visuomenè iš mokytojo tikisi, kad jis atliktų ne tik mokymo proceso organizatoriaus vaidmenį, bet prisiimtų ir kitus vaidmenis (Lotter ir kt., 2020: 39). M. Sowell (2018) pažymi, kad ugdymo įstaigos lyderiu pripažintas mokytojas visada skatins mokinių veiklos efektyvumą. Anot E. Leffler (2019), šiandien mokytojas turi būti stipri asmenybè, gebėti vadovauti, nebijoti rizikuoti, turèti aiškią viziją, daryti kitiems teigiamą ịtaką. Mokytojų lyderystė, mokslininkų (Cheung ir kt., 2018) teigimu, reiškiasi bendradarbiaujant su kitais mokytojais, veiksmingai modeliuojant mokymo(-si) procesą, žinant ir ginant išteklių vadybą bei savo teises.

Lyderystės tyrimuose (Arman ir kt., 2016) skiriami vadovui lyderiui svarbūs intelektiniai gabumai, tokie asmeniniai bruožai kaip dominavimas, komunikabilumas, visuomeniškumas, pasitikẻjimas savimi, energingumas ir kt., kurie skatina veiklos efektyvumą, pradètų darbų tęstinumą, dalijimąsi atsakomybe (Hargreaves ir kt., 2012). Mokyklos vadovui lyderystės kompetencija yra pagrindas, siekiant veiklos valdymo rezultatų, motyvuojant darbuotojus vykdyti pokyčius (Arman ir kt., 2016: 145). Ji sudaro prielaidas plètoti bendruomenès narių kūrybiškumą, kurti besimokančią bendruomenę (Navickaitè, 2015). Progimnazijos vadovas yra veikëjas, gebantis veiksmingai tarpininkauti tarp ịvairių švietimo ir mokymo lygių, šeimų, darbo rinkos ir vietos bendruomenès, siekiant bendro tikslo - gerinti mokinių pasiekimus (Bagdonè, 2015).

Sékminga šiuolaikinė mokykla turi būti veiksmingai valdoma, sisteminis požiūris ị mokyklos vadybą yra vienas iš veiksmingos XXI a. mokyklos reikalavimų (Storey, 2016; McCrey ir kt., 2014). Valdymas siejamas su stabilumo ir tvarkos mokykloje užtikrinimu, veiksmingu vadovavimo, kontrolès, planavimo bei organizavimo funkcijų vykdymu, tuo tarpu lyderystė siejama su socialiniu kontekstu, mokyklos pokyčių užtikrinimo, perspektyvos ir vizijos numatymo, atsakomybès paskirstymo procesais, mokyklos vadovo, lyderio kompetencija (Cibulskas ir kt., 2011: 47).

Lyderystės ir mokyklos veiklos valdymo problemą nagrinèjantys užsienio mokslininkai (Cheung ir kt., 2018; Arman ir kt., 2016; Storey, 2016; Bickmore, 2016; Yuk1, 2012; Marzano ir kt., 2011; Haynes ir kt., 2014; Day, Sammons, 2014; Coughlin, Baird, 2013; Everard ir kt., 2004; ir kt.) ir Lietuvos autoriai (Valuckiené ir kt., 2015; Skarbalienè, 2015; Cibulskas ir kt., 2012 ir kt.) lyderystę supranta kaip vieną iš ateities žinių ir inovacijų augimo, švietimo ịstaigų veiklos kokybės užtikrinimo varomųjų jẻgų. A. Hargreaves'as, D. Fink'as (2012) sẻkmingą lyderystę sieja su mokyklos pažanga. 
A. Skarbalienès (2015) teigimu, kai švietimo sistemoje ịgyvendinama lyderystės idejja, apskritai gerèja švietimo kokybė, nes įtraukiamos visų tipų mokyklos ir įvairūs valdymo lygmenys. J. Storey (2016) pažymi, kad siekiant geriausių rezultatų lyderyste turi reikštis visais mokyklos veiklos lygmenimis.

Lietuvos Respublikos švietimo ir mokslo ministro įsakyme „Dėl geros mokyklos koncepcijos patvirtinimo“ (2015) pažymima, kad mokyklos, kaip organizacijos, veiklos aspektas - lyderystè ir vadyba lemia mokyklos misijos igyvendinimą, bet vis dèlto tai yra tik misijos igyvendinimo sąlygos, o gerų rezultatų galima pasiekti dirbant skirtingais būdais ir ịvairiai organizuojant veiklą. Progimnazija turi atitikti Geros mokyklos koncepcijos (2015) apibréžimą, t. y. būti prasmės, atradimų ir mokymosi sẻkmės siekiančia mokykla, grindžiančia savo veiklą bendruomenès susitarimais ir mokymusi. Šiandien progimnazija toliau kuria savo įvaizdị visuomeneje, todèl vadovo lyderystès problemos tyrimai ypač aktualūs.

Tyrimo problema. Progimnazija, kaip pagrindinį ugdymą teikianti bendrojo ugdymo mokykla, turi atitikti šiuolaikinès ugdymo ịstaigos reikalavimus, susitelkti ties veiklos valdymo veiksmingumu, siekiant ugdymo kokybès, gerinant mokinių mokymosi pasiekimus, kuriant palankią socialinę ir kultūrinę mokymosi aplinką. Progimnazija gali ir turi prisidèti prie naujos mokyklos valdymo kultūros formavimo, kuris be lyderystės ir nuolatinio mokymosi šiandien sunkiai ịsivaizduojamas. Progimnazija, kaip mokyklos tipas, Lietuvoje atsirado visai neseniai. Remiantis Lietuvos Respublikos švietimo ịstatymu (2011, 41 straipsnio 2 dalies redakcija), progimnazijos veikla yra specifiška, moksliniuose darbuose pasigendama konkretaus dèmesio lyderystès raiškai būtent šio mokyklos tipo veiklos valdyme. Todèl atlikto kokybinio tyrimo rezultatai svarbūs lyderystès fenomeno pažinimo ir progimnazijos veiklos valdymo atžvilgiu. Šios problemos moksliniai tyrimai leidžia kaupti mokslinę informaciją apie progimnazijos vadovų lyderystès veiklos valdyme fenomeną.

Tyrimo objektas - progimnazijos vadovų lyderystè veiklos valdyme.

Tyrimo tikslas - atskleisti progimnazijos vadovų lyderystės veiklos valdyme esminius požymius.

Tyrimo metodai: mokslinès literatūros, dokumentų analizè ir sintezė; interviu; fenomenologinè kokybinio tyrimo duomenų analizè ir aprašymas.

\section{Tyrimo metodologija}

Siekiant suprasti, kokią patirti progimnazijų vadovai yra sukaupę apie lyderystės kompetenciją šio tipo mokyklos veiklos valdyme, pasirinktas kokybinis tyrimas, leidžiantis aprašyti realioje aplinkoje vykstančią sąveiką, atpažinti žmonių elgesio strategijas, išgyvenimus (Žydžiūnaitė, Sabaliauskas, 2017). Atliekant kokybinį tyrimą nagrinejjami duomenys išreiškiami žodine forma, pasisakymais, patirtimi, turima kompetencija, kas padeda ịsigilinti į mažai tyrinètą reiškinị (Bryman, 2017). Tyrimo duomenys rinkti taikant interviu (iš dalies struktūruoto) metodą, kaip vienas patogiausių ir patikimiausių, kuriuo galima surinkti nemažai nestruktūruotos informacijos apie tiriamą problemą (Rupšienè, 2007; Hesse-Biber, Leavy, 2011).

Tirti pasirinkta viena iš kokybinio tyrimo strategijų - fenomenologija, pagal kurią tiriant fenomenus atskleidžiami žmogiškujų išgyvenimų prigimtis ir būdai. Remdamasis iš informantų surinktais duomenimis, tyrejjas atskleidžia savo supratimą, siekį atrasti, kas bendra ir kas individualaus yra jų pasisakymuose, o tai skatina atskleisti fenomeno esmę. Informantų patirtis ir jos raiška kiekvieno pasisakymuose atskleidžia šios patirties turini (Bitinas ir kt., 2008, I, p. 123-124; Flowers ir kt., 2009). Fenomenologijoje esama didelès požiūrių įvairovès, tačiau filosofinès prielaidos remiasi gyvo potyrio studijavimu, požiūriu, kad šios patirtys yra sąmoningos, jomis grindžiami fenomenų paaiškinimai (Moustakas, 1994). Fenomenologija prasminga tada, kai tyrèjas tikisi suprasti fenomeną, siekdamas užtikrinti geriausią praktiką (Creswell, 2012). Laikantis fenomenologijos tradicijos (Creswell, 2012), taip galima ištirti ir progimnazijų vadovų patirtị bei jos raišką pasisakymuose apie lyderystę veiklos valdyme, kurie geriausiai atitinka šios patirties turinị. Remiantis J. W. Creswell'u (2012), interviu surinktų duomenų turinys laikomas vertingu, nes padeda suprasti progimnazijų vadovų patirtị ir suformuluoti teorinius apibendrinimus.

Tyrimo imtis. Progimnazijos vadovo lyderystès kompetencijoms mokyklos veiklos valdyme tirti kaip pagrindinė tikslinė grupe pasirinkti progimnazijų vadovai, nes kitų mokyklų atžvilgiu progimnazija, kaip mokyklos tipas, turi savo specifiką (LR Švietimo įstatymas, 2011). Tyrime dalyvavo penki vadovai iš 
Lietuvos Vakarų regiono progimnazijų (Klaipėda, Šilutė, Kretinga, Tauragė). Taikant individualų interviu, tokios imties pakanka, nes rekomenduojamas imties dydis - nuo 5 iki 30 žmonių (Rupšienè, 2007: 34), kokybiniai tyrimai padeda tirti atvejus, nesiekiant reprezentatyvumo (Žydžiūnaite ir kt., 2017). Dalyvauti tyrime vadovai pasirinkti tikslinès kriterinès atrankos būdu (Rupšienè, 2007, p. 32). Šiuo atveju buvo svarbūs šie kriterijai: a) darbas progimnazijoje; b) darbo patirtis (tyrime dalyvavo vadovai, turintys ne mažiau kaip 20-ies metų darbo stažą) ir c) vadovų vadybinè kategorija.

Tyrimo dalyvių charakteristika. Atliktas interviu, kuriame dalyvavo penkių progimnazijų vadovai. Pirmasis informantas (I1) - 52 metų moteris, turinti 27-erių metų darbo stažą ir II vadybinę kategoriją. Antrasis informantas (I2) - 59 metų vyras, turintis 39-erių metų darbo stažą ir II vadybinę kategoriją. Trečiasis informantas (I3) - 60 metų vyras, turintis 43 -ejų metų darbo stažą ir II vadybinę kategoriją. Ketvirtasis informantas (I4) - 45 metų moteris, turinti 21-erių metų darbo stažą ir mokytojo metodininko vadybinę kategoriją. Penktasis informantas (I5) - 48 metų moteris, turinti 24-erių metų darbo stažą ir II vadybinę kategoriją. Informantai gerai pažista vadovaujamos progimnazijos organizaciją, jiems žinoma šio mokyklos tipo veiklos valdymo specifika, todẻl interviu dalyvavę progimnazijų vadovai galèjo pateikti realią situaciją atskleidžiantị lyderystės raiškos mokyklos veiklos valdyme supratimą.

Taikydamas individualų kryptingą interviu metodą, tyrejjas numato temas arba problemas, kurias aptars atlikdamas interviu, bet „neprisiriša“ prie klausimų tvarkos ar numatytų pasakyti žodžių, laisvai juos keičia vietomis, užduoda papildomų klausimų (Rupšienè, 2007, p. 67-68). Atliekant ši tyrimą pirmiausia buvo numatyta aptarti tokias temas: 1) vadovo lyderystẻ progimnazijos veiklos valdyme; 2) vadovo lyderyste ị veiklos valdymą įtraukiant progimnazijos bendruomenès narius; 3 )vadovo lyderyste ị progimnazijos veiklos valdymą issitraukiant kitiems bendruomenès nariams; 4) vadovo lyderystè, siekiant mokytojų lyderystès progimnazijoje; 5) vadovo lyderystè vertinant progimnazijos veiklos valdymą; 6) progimnazijos vadovų lyderyste, siekiant veiklos valdymo veiksmingumo; 7) progimnazijos veiklos valdymo veiksmingumo priemonès.

Fenomenologinè kokybinio tyrimo duomenų analizė numato tyrèjo fenomenologinę intuiciją ir gautų kokybinių rezultatų aprašymą (Bitinas ir kt., 2008, II, p. 90). Siekiant tyrimo tikslo taikytas gautų duomenų fenomenologinio aprašymo metodas (Moustakas, 1994).

\section{Tyrimo rezultatai}

Pirmoji interviu metu iškilusi tema - vadovo lyderyste progimnazijos veiklos valdyme. Išskirtos potemès: progimnazijos vadovas lyderis, progimnazijos administracijos nariai, progimnazijos metodinès tarybos nariai, progimnazijos mokytojų tarybos nariai, kiti progimnazijos bendruomenès nariai.

Vadovai pažymėjo, kad progimnazijos veiklos valdyme didžiausia atsakomybe tenka jiems: ,...didžiausia atsakomybè vadovui“ (I1); ,...progimnazijos direktoriui tenka atsakomybė, jis turi būti lyderiu“ (I2); ,...vadovas kaip mokyklos lyderis yra atsakingas“ (I3); ,...mokyklos veiklos valdyme sprendimai priklauso nuo vadovo lyderio gebėjimo telkti kitus“ (I4); „,...progimnazijos valdyme reikia greito reagavimo, todèl kaip komandos lyderis turiu nuspręsti greitai“ (I5). Tad progimnazijos veiklos valdyme vadovai išskiria savo, kaip lyderio, vaidmenį ir atsakomybę. Informantai išskyrè ir kitų administracijos narių vaidmenị progimnazijos veiklos valdyme: ,,...atsakinga ir administracija“ (I3; I2); ,...direktoriaus pavaduotojai“ (I4); ,...mokyklos valdyme dalyvauja ir kiti administracijos atstovai, pavaduotojai“ (I1). Informantai pažymėjo, kad progimnazijos metodinès tarybos nariai yra svarbūs mokyklos veiklos valdymo proceso dalyviai: ,...svarbūs valdyme metodinès tarybos nariai“ (I2); ,...progimnazijos metodinès grupès, tarybos nariai“ (I5). Progimnazijos veiklos valdyme, informantų teigimu, svarbūs mokytojų tarybos nariai: „,...sudarau galimybę sprendimus priimti pedagogų taryboje“ (I1); ,....mokytojų posėdžių metų taip pat priimami sprendimai, kurie svarbūs progimnazijos veiklos valdymui““ (I3). Informantų nuomone, progimnazijos veiklos valdyme svarbūs ir kiti bendruomenès nariai: ,...tèvų dalyvavimas mokyklos valdyme“ (I3); ,...progimnazijos mokinių tarybos veikla“ (I4); ,...valdyme svarbi veikla su socialiniais partneriais“ (I1); ,...tèvai ir mokinių taryba“ (I2).

Progimnazijos veiklos valdymo sprendimai priimami ne tik ugdymo ịstaigos vadovo ir kitu administracijos atstovų, šiame procese, informantų nuomone, svarbūs ir mokytojų, mokinių tarybos nariai, tėvai, 
socialiniai partneriai. Tai atskleidžia tyrime dalyvavusių vadovų supratimą ir gebẻjimą telkti progimnazijos bendruomenę bendriems tikslams, prisiimti atsakomybę už progimnazijos veiklos valdymą.

Kita atliekant interviu išryškejjusi tema - vadovo lyderyste ị veiklos valdymą įtraukiant progimnazijos bendruomenès narius. Išskirtos šios potemės: posėdžių ir pasitarimų organizavimas; bendruomenės narių iniciatyvų dèl veiklos valdymo aptarimas; diskusijos ir forumai; darbo grupių veikla. Progimnazijų vadovai atskleidè, kokiomis formomis ir kaip jie įtraukia bendruomenès narius į mokyklos veiklos valdymą. Viena iš formų - reguliariai organizuojami posėdžiai, pasitarimai, kuriuose „teikiami ir svarstomi pastebejjimai, siūlymai dèl veiklos valdymo, priimami sprendimai“ (I2); ,progimnazijos tarybos posèdžių organizavimas aktualiems veiklos valdymo klausimams spręsti“" (I1).

Kitas įtraukimo būdas - bendruomenès narių iniciatyvų aptarimas: ,....tèvelių iniciatyva svarbi, todèl buriamès ị reguliarius susirinkimus svarbiems mokyklos gyvenimo ir valdymo aspektams aptarti, tobulinimo kryptims numatyti“ (I5); ,...patys pedagogai kasmet inicijuoja anonimines apklausas, siekdami kritiškai ịvertinti progimnazijos veiklos valdymą, jų analizè bendrai aptariama“ (I4); ,...prieš didžiąsias šventes progimnazijos bendruomenèje ypač padaugẻja ịvairių pasiūlymų, kaip organizuoti veiklas, jie yra bendrai aptariami““(I4; I1; I5).

Progimnazijų vadovai organizuoja diskusijas ir forumus aktualiems veiklos valdymo klausimams aptarti: „....susirenkame ị mokyklos forumus, kurių metu svarstomi aktualūs valdymo ir kiti klausimai, ieškoma vieningų sprendimų“ (I1); ,...nuolat kviečiu diskusijai“ (I2). Vadovų lyderystė reiškiasi ir darbo grupių veikloje: „,...pagal veiklos sriti esame pasiskirstę, veikia darbo grupès“ (I3); ,...turime progimnazijos savivaldos darbo grupę“ (I4). Informantų nuomone, darbo grupių veikla skatina mokinių ir mokytojų aktyvumą: ,...darbas grupėse ịkvepia ir mokinius“ (I3); ,...mokiniai aktyviau dalyvauja ịvairioje veikloje“ (I5)“; ,...darbo grupėse mokytojai vieni kitus skatina judèti pirmyn, kuriama tarpusavio pasitikèjimo atmosfera“ (I4; I2).

Progimnazijos vadovų lyderystės raišką atskleidžia tos formos, kurios labiausiai atskleidžia mokyklos bendruomenès narių ịtraukimą ị veiklos valdymą: tarybos posėdžių organizavimas, bendruomenès narių (tėvų, pedagogų) teikiamų iniciatyvų, pedagogų inicijuojamų anoniminių apklausų dèl mokyklos veiklos valdymo analizès aptarimas, diskusijos ir forumai aktualiais veiklos valdymo klausimais, darbo grupiu sutelkimas, skatinantis mokinių ir mokytojų aktyvumą, puoselëjantis tarpusavio pasitikèjimo atmosferą.

Trečioji atliekant interviu iškilusi tema - vadovo lyderystè ị progimnazijos veiklos valdymą ịsitraukiant kitiems bendruomenès nariams. Išskirtos šios potemès: bendrų tikslų siekimas, organizuojami renginiai, ugdymo ir veiklos planų derinimas, progimnazijos ugdymo(si) kokybės kaita, pedagogų dalyvavimas valdymo sambūriuose, projektinè veikla.

Informantai pažymejjo, kad kiti nariai įsitraukia ị veiklos valdymą siekdami bendrų progimnazijos tikslų: „,...bendrų tikslų siekimas padeda ịsitraukti kitiems nariams“ (I4); ,...vieningai siekiama užsibrěžtų progimnazijos tikslų“ (I1); ,...bendradarbiaujama su bendruomenės nariais keliant ir igyvendinant užsibrēžtus tikslus“ (I5). Kitas įsitraukimo ị veiklos valdymą būdas, informantų teigimu, yra renginiai, puoselèjantys bendruomeniškumą ir skatinantys mokinių savivaldą: ,,...organizuojami renginiai ne tik progimnazijoje, bet ir mieste“ (I4); ,... i organizuojamus renginius ịsitraukia visa mokyklos bendruomenë“ (I3); ,...bendruomeniškumą stipriname reguliariai kviesdami į tradicija tapusius mokyklos renginius“ (I5); ,,..originalios šventės ir kiti susibūrimai skatina įsitraukti ị progimnazijos veiklos valdymą“ (I1); ,...dalyvavimu renginiuose aktyviai skatinama mokinių savivalda" (I2).

Informantai pažymejjo, kad progimnazijos bendruomenès nariai ịsitraukia ị veiklos valdymą, rengdami ir derindami ugdymo bei veiklos planus: ,....strateginiai veiklos planai rengiami ir derinami“ (I1); ,....rengiant mokyklos planus, būtinai juos deriname“ (I2); ,...derinami rengiami ugdymo veiklos, strateginiai progimnazijos planai, vadovas koordinuoja jų igyvendinimą"(I5). Dalyvaujant progimnazijos veiklos valdyme, gerëja ugdymo(si) kokybė: ,...galima stebèti gerèjančią ugdymo(si) kokybę“ (I1); didèja mokinių aktyvumas, gerèja akademiniai pasiekimai: ,...mokiniai noriai ịsitraukia ị pilietišką veiklą“ (I3); ,...pasiekia aukštų akademinių rezultatų tiek rajono, tiek Respublikos mastu“ (I5); „,...turi reikšmès mokinių ugdymosi pasiekimams“ (I4); ,...ryškejja mokinių organizuotumas“ (I2).

Tyrimu atskleista, kad pedagogai vadovo skatinami ịsitraukti ị veiklos valdymo procesą dalyvaujant ịvairių sambūrių veikloje: ,,...skatinu dalyvauti progimnazijos taryboje“ (I2); „,...svarbus įsitraukimas ị metodinių ir 
kitu grupių veiklą، (I3); ,...dalyvavimas metodiniuose renginiuose ugdymo(si) kokybei gerinti““(I2). Progimnazijų vadovai savo lyderystę reiškia skatindami pedagogus dalyvauti projektinėje veikloje: „,...ivvairūs projektai padeda įsitraukti ị progimnazijos valdymą“ (I1); ,....mūsų progimnazijoje sèkmingai rengiami ir vykdomi projektai“ (I4); ,....aktyvus dalyvavimas projektineje veikloje svarbus geram mokyklos valdymui““(I5).

Progimnazijos bendruomenès nariai progimnazijos veiklos valdyme reiškiasi ịvairiai: kartu su vadovais siekia bendrų organizacijos tikslų, organizuoja ịvairius renginius mokykloje ir už jos ribų, derindami ugdymo ir veiklos planus, dalyvaudami progimnazijos ugdymo(si) kokybės kaitos procese. Progimnazijos bendruomenès narių ịsitraukimas ị mokyklos veiklos valdymą reiškiasi kaip mokinių aktyvumas, akademiniai pasiekimai, pilietiškumas, organizuotumas, pedagogu ịsitraukimas dalyvaujant mokyklos valdymo sambūrių ir projektinèje veikloje. Progimnazijos pedagogai, mokiniai ir kiti bendruomenès nariai vadovo lyderystès paskatinti prisideda prie mokyklos veiklos valdymo, neretai priima su valdymu susijusius sprendimus, aktyviai organizuoja ịvairias veiklas, taip puoselėdami progimnazijos bendruomeniškumą, mokinių savivaldą ir pilietiškumą.

Ketvirtoji atliekant interviu iškilusi tema - vadovo lyderystė, skatinant mokytojų lyderystę progimnazijoje. Išskirtos šios potemès: sąlygos dalyvauti progimnazijos veiklos valdyme, mokytojų iniciatyvų palaikymas, dalijimasis lyderystès patirtimi, mokytojų motyvavimas. Informantų teigimu, progimnazijoje sudaromos sąlygos mokytojams dalyvauti veiklos valdyme: ,....sudarome sąlygas, siekdami įtraukti pedagogus ị progimnazijos veiklos valdymą“ (I4); ,...mokytojai raginami išsakyti nuomonę mokyklos valdymo klausimais“ (I3); ,....progimnazijoje sukuriamos sąlygos laisvai veikti“ (I5); ,...veiklos valdyme svarbus pasitikèjimas darbuotoju“ (I5).

Vadovai skatina lyderystę, palaikydami mokytojų iniciatyvas: ,... nesiekiu užkirsti kelio jų (darbuotojų - aut. past.) iniciatyvoms“ (I3); „,..visapusiškas iniciatyvų palaikymas“ (I2). Informantai pažymėjo, kad progimnazijoje dalijamasi lyderystès patirtimi: ,...visada patariu veiklos valdymo klausimais““(I2); ,...igyta lyderystès veiklos valdyme patirtis leidžia ją skleisti bendruomenėje“ (I1); ,...informacija apie mokytojų lyderystès pavyzdžius bei jų iniciatyvas skleidžiama visuomenèje“ (I4); ,...lyderystė palaikoma dèl veiklos valdymo kokybės“ (I1; I4); ,...parodomas vadovo asmeninis dėmesys“ (I5). Informantai ypač akcentavo iniciatyvių progimnazijos mokytojų motyvavimą. Vadovai mano, kad skatinant mokytojų lyderystę veiklos valdyme, svarbu sudaryti sąlygas, kad jie galètų tobulinti savo kvalifikaciją: ,...manau, kad sudarome puikias sąlygas tobulinti savo pedagoginę kvalifikaciją“ (I2); ,...daug dèmesio skiriama pedagogų kvalifikacijos tobulinimui“ (I3); ,... kvalifikacijos tobulinimas yra viena iš darbuotojo motyvavimo priemonių veiklos organizavime“ (I5); ,...kvalifikacijos tobulinimo galimybès yra, kursai net „atvežami“ i mokyklą“ (I1).

Progimnazijų vadovai pažymejjo, kad svarbu skatinti mokytojų lyderystę. Pirmiausia jie pažymi paskatinimą žodžiu: ,...nevengiu pasakyti gero žodžio čia ir dabar“ (I2); ,...žodinis pagyrimas mokytojui labai svarbus“ (I1); ,...mokytojui reikia nuoširdžiai padẻkoti už lyderystės raišką“ (I3). Kaip ne mažiau svarbias paskatas vadovai ịvardijo: ,...padèkos raštus“ (I1); ,...suvenyrus“ (I2); ,...nuolatini darbuotojų pagerbimą už veiklos rezultatus“ (I5). Minètas ir materialus pedagogų skatinimas: „,...tam tikrais švietimo ịstaigų veiklą reglamentuojančių dokumentų nustatytais atvejais darbuotojai yra skatinami materialiai“ (I4); ,...esant galimybei, mokytojams teikiamas finansinis paskatinimas“ (I3; I4). Pažymėtina, kad atliekant interviu šia tema nè vienas informantas nenurodè neigiamos reakcijos.

Vadovai lyderystę, siekiant mokytojų lyderystę ịtvirtinti visais progimnazijos lygmenimis, demonstruoja sudarydami sąlygas jiems dalyvauti progimnazijos veiklos valdymo ir nuolatinio kvalifikacijos tobulinimo procesuose, palaikydami jų iniciatyvas, dalindamiesi su jais lyderystės patirtimi, motyvuodami veiklai žodžiu, palaikymu bei materialiai.

Analizuojant penktą atliekant interviu iškilusią temą - vadovo lyderystė progimnazijos veiklos valdymo vertinime, išskirtos potemės: mokinių pasiekimų ir pažangos vertinimas, veiklos valdymo tyrimai, vidaus vertinimo tvarka, veiklos rezultatų analizè ir refleksija.

Tyrime dalyvavę progimnazijų vadovai išskyrẻ lyderystę vertinant mokinių pasiekimus ir pažangą: „,...reguliariai stebima mokinių mokymosi pažanga“ (I4); ,...užtikrinamas formalus ir neformalus pažangos ir pasiekimų vertinimas“ (I1); ,...naudojamas el. dienynas, vertinama pažymiais bei lygiais, mokiniai savo pažangą stebi specialiuose sąsiuviniuose, kaupia pagyrimus ir pan.“ (I2); ,...kiekvienas pedagogas turi aiškiai apibrèžtą mokinių pažangos ir pasiekimų vertinimo sistemą“ (I5); ,...trimestrui pasibaigus, rengiamos, 
o vèliau metodinėse grupèse analizuojamos mokinių pažangumo ataskaitos“ (I3); ,,...veikla organizuojama taip, kad progimnazijoje vertinimas vyksta kiekvienoje pamokoje“(I1).

Informantai pažymejjo, kad progimnazijoje nuolat vykdomi veiklos valdymo vertinimo tyrimai: „,...veiklos valdymui vertinti pasitelkiame klausimyną“ (I2); ,...inicijuojami tyrimai progimnazijos viduje, kurių rezultatais remiantis siekiama identifikuoti kylančias problemas bei rasti jų įveikos būdus“" (I5). Be to, nustatyta progimnazijos vidaus vertinimo tvarka: ,...mokykloje turime konkrečiai apibrèžtus tvarkos aprašus, kurių siekiame laikytis“ (I2); „...remiamasi mokyklų veiklos kokybės įsivertinimo metodika“ (I3). Vadovų lyderyste reiškiasi reguliariai vykdant progimnazijos veiklos rezultatų analizę: ,....ar buvo pasiekti numatyti tikslai, įvertiname analizuodami nuveiktus darbus“ (I2); ,...veiklos tyrimų išvados analizuojamos, reflektuojamos, tai vyksta nuolat" (I1).

Gilinantis ị vadovų lyderystès vertinant progimnazijos veiklos valdymą supratimą, išryškẻjo, kad tyrime dalyvavusiose progimnazijose vyksta nuolatinis mokinių mokymosi pažangos stebëjimas, formalus bei neformalus pažangos ir pasiekimų vertinimas, pedagogai taiko aiškiai apibrèžtą pasiekimų vertinimo sistemą. Ne mažiau svarbi ir vadovų nuomonė apie veiklos valdymo vertinimo vidaus tyrimus, kurie padeda ne tik atpažinti kylančias problemas, bet ir surasti jų sprendimo būdų. Numatytų progimnazijos veiklos tikslų ir rezultatų nuolatinè analizė bei refleksija leidžia įžvelgti vadovų lyderystės reikšmę progimnazijos veiklos valdymui.

Šeštoji atliekant interviu iškilusi tema - progimnazijos vadovų lyderyste, siekiant veiklos valdymo veiksmingumo. Šios temos analizei išskirtos potemès: vadovo ir mokytojų lyderystès kompetencija, tvarūs bendruomenès tarpusavio ryšiai, mikroklimatas, bendruomenès narių ir socialinių partnerių įsitraukimas ị veiklos valdymo procesą, progimnazijos ịvaizdis visuomenèje.

Progimnazijų vadovai pažymėjo, kad, siekiant veiklos valdymo veiksmingumo svarbi vadovo ir mokytojų lyderystès kompetencija: ,...didelę reikšmę teikiu vadovo ir lyderio kompetencijai“ (I4); ,...gebẻjimas vadovauti, būti lyderiu“ (I3); ,...vadovo lyderyste““ (I5); ,...neabejotinai, pedagogų kompetencija ir lyderyste““ (I3; I5); ,...mokytojų lyderystë“ (I4). Informantų nuomone, siekiant veiklos valdymo veiksmingumo svarbūs tvarūs bendruomenès narių tarpusavio ryšiai: ,...reikšmę turi darnus mokyklos bendruomenės narių bendradarbiavimas“ (I5); ,...mokinių tėvų, pačių mokinių ir pedagogų ịsitraukimas ị veiklos valdymą“ (I2; I3); ,...bendravimas ir bendradarbiavimas tarp progimnazijos bendruomenės narių“(I1); ,...darnus dalyvavimas bendroje veikloje“(I4).

Vadovai pastebi, kad siekiant progimnazijos veiklos valdymo veiksmingumo ypač svarbus organizacijos mikroklimatas: ,....bendra atmosfera kolektyve“ (I1); ,...tai, kaip bendraujame vieni su kitais, koks yra pasitikèjimas, kokia savitarpio pagalba“ (I3); ,...palankus mikroklimatas progimnazijoje“ (I4).

Siekiant progimnazijos veiklos valdymo veiksmingumo svarbus bendruomenès ir socialiniu partnerių įsitraukimas. Informantai akcentuoja mokiniu įsitraukimą: ,....mokiniai savo ịsitraukimu padeda efektyviam valdymui“ (I1); ,...mokinių nuomonè svarbi teikiant įvairius pasiūlymus“( (I2). Jie mini ir mokinių tèvų ịsitraukimą: ,...tèvai ịsitraukdami ị veiklą padeda ịgyvendinti ịvairias idejjas“ (I5); ,...mokinių tèvai prisideda prie veiklų organizavimo“ (I1); ,...tèvai aktyviai dalyvauja susibūrimuose, teikia pasiūlymus, padeda siekti progimnazijos užsibrèžtu tikslų“ (I2); ,...svarbus tèvų indèlis ị mokyklos veiklą“ (I3). Vadovai, dalyvavę tyrime, pažymėjo socialinių partnerių įtraukimo svarbą: ,,...mūsų partnerių palaikymas labai svarbus veiklos valdymo efektyvinimui“ (I5); ,...progimnazijoje palaikoma partnerystė su socialiniais partneriais“(I3); „...kartais socialiniai partneriai ,atveria duris“ (I4).

Analizuojant interviu duomenis, išryškèjo nauja vadovų patirtis dèl besikeičiančio progimnazijos ịvaizdžio visuomenejje, augančio šio tipo mokyklos populiarumo: ,...malonu, kai sklinda pozityvios kalbos apie progimnaziją“ (I2); ,...progimnazijos ịvaizdị formuoja geri aplinkinių atsiliepimai“ (I4); ,...visada malonu priimti iš kitų pagyrimus apie progimnaziją“ (I3). Informantai pažymėjo, kad progimnazijos tipo mokyklų populiarumas auga: ,...kasmet mokyklą lankyti norinčių vaikų skaičius auga“ (I4); ,...sukomplektuojame vis daugiau progimnazijų klasių“ (I5); ,...palaipsniui didejja progimnazijos populiarumas“(I1).

Progimnazijos vadovų lyderystė svarbi siekiant veiksmingo veiklos valdymo. Ne tik progimnazijų vadovams, bet ir mokytojams svarbi lyderystès kompetencija. Siekiant veiklos valdymo veiksmingumo, svarbūs tvarūs progimnazijos bendruomenès narių tarpusavio ryšiai, mokinių, tėvų ir pedagogų bendradarbiavimas bei darni visų veikla, progimnazijos, kaip organizacijos, mikroklimatas. Mokinių, tėvų, mokytojų teikiami 
pasiūlymai dèl veiklos valdymo ir ịsitraukimas, socialinių partnerių palaikymas padeda siekti užsibrèžtu tikslų, progimnazijos veiklos ir jos valdymo veiksmingumo. İžvelgta, kad progimnazijos ịvaizdis visuomenejje kinta, auga šio tipo mokyklos populiarumas.

Šiuolaikinès progimnazijos vadovai ieško būdų, kaip siekti mokyklos valdymo veiksmingumo, kaip sèkmingiau valdyti ịvairius kaitos procesus. Tyrime dalyvavę progimnazijų vadovai yra savo srities profesionalai, galintys išreikšti savo supratimą apie mokyklą kaip vieningą visumą. Jų vadybinis pasirengimas ịgalina ne tik įvertinti mokyklą kaip visumą, bet ir numatyti jos valdymo veiksmingumo skatinimo priemones.

Septintoji atliekant interviu iškilusi tema - progimnazijos veiklos valdymo veiksmingumo priemonès. Išskirtos šios potemès: veiklos valdymo koordinavimas, veiklos valdymo analizės vykdymas, ugdymo ir veiklos planų rengimo bei vykdymo stebėsenos koordinavimas, progimnazijos socialinių ryšių plètojimas, darbo ir ugdymo(si) sąlygų gerinimas, inovacijų paieška bei diegimas, mokytojų kvalifikacijos tobulinimas, savišvietos ir lyderystès skatinimas.

Vadovų nuomone, veiksminga priemone laikytinas veiklos valdymo koordinavimas: ,...svarbu reguliariai ịsivertinti ir gerinti veiklos valdymą" (I5); ,...koordinuoti progimnazijos tikslu ịgyvendinimą per projektinę veiklą“ (I3); „...tikslinga inicijuoti progimnazijos veiklos valdymo kokybės tobulinimo praktinius seminarus“(I4).

Viena iš priemonių yra ugdymo(si) kokybės valdymo koordinavimas, organizuojant ugdymo proceso dalyvių nuomonės tyrimus: ,,...išskirčiau organizuojamus ugdymo(si) proceso dalyvių nuomonės tyrimus“(I1). Vadovų nuomone, veiklos valdymo kokybės priemonė yra vidinis ir išorinis vertinimas: „...pagal mokyklų isivertinimo metodiką atliekamas vidinis veiklos vertinimas“ (I5); ,...vidinis vertinimas / įsivertinimas atspindi, ar pasiekti numatyti tikslai“ (I2); ,...svarbus ir išorinis vertinimas“ (I3); ,...išorinis vertinimas leidžia matyti valdymo pažangą ir trūkumus“ (I4). Kita išskirta priemonè - veiklos valdymo analizė: „...svarbu, kad veiklos valdymas būtų analizuojamas kryptingai ir reguliariai“ (I5); ,...kryptingai analizuoti savo veiklą, remiantis veiklos valdymo efektyvumo vertinimo metodikomis“(I3). Progimnazijų vadovai kaip veiksmingas mokyklos veiklos valdymo priemones išskyrė ugdymo ir veiklos planų rengimo bei vykdymo stebėsenos koordinavimą: ,....atsakingas ugdymo bei veiklos planų rengimas bei koordinavimas“ (I1); ,...turètų būti papildomi ištekliai planų rengimui ir igyvendinimui stebėti“ (I2); ,...galima įsteigti progimnazijoje darbo grupę, kuri būtų atsakinga už planų rengimą, koordinuotų ir stebėtų jų vykdymą, teiktų konsultacijas" (I5).

Kita progimnazijos veiklos valdymo veiksmingumo priemonè - socialinių ryšių plètojimas: „,...progimnazija turi ne tik palaikyti ryšį su esamais socialiniais partneriais, bet ir ieškoti naujų“ (I2); ,...imanoma inicijuoti socialinių ryšių plètrą, tai efektyvintų veiklą“ (I3). Darbo ir ugdymo(si) sąlygų gerinimas yra svarbi veiklos valdymo priemonè: ,....svarbi priemonè į mokyklą pritraukti lěšas, kurios pagerintų ugdymo(si) sąlygas“ (I4; I5); ,...turi būti gerinamos ir darbo sąlygos“ (I3); ,...dalyvavimas konkursuose yra vienas iš būdu pagerinti progimnazijos materialias sąlygas“ (I5); „,...geresnès sąlygos ugdymo(si) procesui neformalioje aplinkoje (sporto, meno)“ (I4); ,...naujų erdvių paieška ir pritaikymas mokymuisi“ (I1); ,...teikti paraiškas projektams, gautas lěšas panaudoti (...) sąlygų gerinimui“ (I2). Pasiūlius progimnazijos bendruomenei geresnes aplinkos ir erdvių kūrimo sąlygas galima reikšmingai pagerinti veiklos valdymą.

Vadovai išskyre tokią priemonę, kaip inovacijų paieška ir diegimas progimnazijoje: ,...inovacijų diegimas mokykloje yra šiandien labai svarbus“ (I5); ,...tikslinga siųsti mokytojus ị inovacijų parodas, parsivežtas įdomias idejjas ịgyvendinti mokykloje“ (I1); ,...ieškoti inovatyvių veiklos progimnazijoje organizavimo būdų ir galimybių, kaip inovacijas diegti mokykloje“ (I3). Vadovų nuomone, veiksminga veiklos valdymo priemone - investavimas ị mokytojų kvalifikacijos tobulinimą. Labai svarbu skatinti mokytojų savišvietą ir lyderystę, rodyti gerą lyderystės pavyzdį: ,... reikètų daugiau lěšų progimnazijos mokytojų kvalifikacijos tobulinimui“ (I2); ,...sudaryti sąlygas pedagogams kvalifikaciją tobulinti nuolat“ (I5); ,...rodyti nuoširdu palankumą jų darbui bei idèjoms, gerus lyderystès raiškos pavyzdžius“"(I3).

Vadovų išskirtos progimnazijos veiklos valdymo veiksmingumo priemonès iš esmės atskleidžia jų, kaip švietimo vadybininkų, funkcijas: koordinuoti, analizuoti, organizuoti veiklas, vykdyti stebėseną. Siekiant progimnazijos veiklos valdymo veiksmingumo, svarbi vadovų lyderystè, kuri reiškiasi nuolat organizuojant ịstaigos įsivertinimo ir ugdymo proceso dalyvių nuomonių tyrimus, aktyviai dalyvaujant projektineje veikloje, rengiant ugdymo ir veiklos planus bei vykdant jų stebèseną, gerinant darbo ir ugdymo(si) sąlygas, pri- 
traukiant ị progimnaziją lěšų naujovėms ir inovacijoms diegti, tobulinantis veiklos valdymo kokybès srityje, skatinant mokytojų savišvietą ir lyderystę.

Tyrimo rezultatų apibendrinimas. Interviu su progimnazijų vadovais atskleidè esminį vadovo lyderystės veiklos valdymo požymį - vadovas pirmiausia pats prisiima atsakomybę už mokyklos veiklos valdymą, kartu šiam darbui telkia ir kitus bendruomenès narius: administracijos atstovus, mokytojų ir mokinių tarybas, tėvus, socialinius partnerius. Taip siekiama bendrų progimnazijos tikslų, skatinama pasidalyti atsakomybe. Tokia vadovų veiklos valdymo dalyvių samprata siejasi su A. Skarbalienès (2015) teiginiu, kad mokyklų vadovai, turintys stiprią mokytojų lyderių komandą, užtikrina didesnį kūrybinị ir idèjinį organizacijos potencialą, galimybes plètoti veiklą bei puoselèti ryšius.

Progimnazijų vadovai lyderystę išreiškia įvairiomis formomis įtraukdami bendruomenès narius ị veiklos valdymą. Tarybos posėdžiai, bendruomenès narių (tėvų, pedagogų) teikiamų iniciatyvų aptarimas, pačių pedagogų vykdomų anoniminių apklausų duomenų analizé, diskusijos ir forumai, darbo grupių telkimas skatina tarpusavio pasitikejjimo atmosferą, aktyvina mokinius ir mokytojus. Kaip akcentuojama ịvairių tyrèjų tyrimuose, kitų lyderių pripažinimas mokyklos lygmeniu sudaro sąlygas jiems būti aktyviems ir skatina imtis atsakomybės (Valuckienė ir kt., 2015), formuojama palanki terpe gerosios patirties sklaidai, tvariam tarpusavio bendravimui ir bendradarbiavimui (Hargreaveas ir kt., 2012).

Interviu atskleidè bendruomenès narių ịsitraukimo ị progimnazijos veiklos valdymą požymị. Siekdami bendrų progimnazijos tikslų vadovai kartu su kitais bendruomenės nariais organizuoja ịvairius renginius mokykloje ir už jos ribų, derina ugdymo ir veiklos planus, dalyvauja ugdymo(si) kokybès kaitos procese, įsitraukia ị valdymo sambūrius ir projektinę veiklą. Mokinių dalyvavimas savivaldoje skatina jų pilietiškumą ir organizuotumą, gerèja ir akademiniai pasiekimai. R. McCray’us ir kt. (2014) pažymi, kad mokinių pažangumo rodikliai yra būtent tie vertinimo kriterijai, pagal kuriuos galima spręsti apie mokyklos darbo veiksmingumą.

Vadovo lyderystę veiklos valdymo procese atskleidè mokytojų lyderystės įsitvirtinimas progimnazijoje. Sudarydami sąlygas mokytojams dalyvauti progimnazijos veiklos valdyme ir nuolat tobulinti kvalifikaciją, palaikydami mokytojų iniciatyvas, dalydamiesi su jais lyderystès patirtimi, motyvuodami mokytojus veiklai žodžiu, palaikymu ir materialiomis priemonėmis, vadovai siekia administracijos, mokytojų santykių darnos ir abipusio pasitikèjimo. Tai patvirtina kitų tyrimų rezultatus, kad teigiamas požiūris ir vadovo palaikymas tampa ne tik puikia bendruomenès narių motyvavimo priemone, bet ir skatina juos nuolat tobulèti (Haynes ir kt., 2014). Todèl svarbu tarpusavyje derinti įvairias bendruomenès narių motyvavimo formas (Haynes ir kt., 2014), siekiant įtvirtinti lyderystę visais progimnazijos lygmenimis (Storey, 2016). R. J. Marzano ir kt. (2011) savo tyrimuose pažymi, kad mokyklos lyderystẻ lemia sẻkmę daugelyje mokyklos sričių.

Vadovo lyderystė veiklos valdymo procese reiškiasi, kai ieškant veiksmingų veiklos valdymo sprendimų progimnazijoje atliekamas nuolatinis mokinių mokymosi pažangos stebẻjimas, formalus ir neformalus pažangos bei pasiekimų vertinimas, skatinama naudotis aiškiai apibrèžta pasiekimų vertinimo sistema, vykdomi veiklos valdymo vertinimo vidaus tyrimai, analizuojami bei reflektuojami veiklos tikslai ir rezultatai. Kaip pažymima kituose tyrimuose, lyderystė suburia asmenis siekti bendro tikslo (Northouse, 2016). Interviu duomenys atskleidè dar vieną esminị vadovo lyderystės veiklos valdymo požymį - siekị nuolat tobulinti veiklos valdymą. Darnius progimnazijos bendruomenès narių tarpusavio ryšius vadovai išskiria kaip svarbią lyderystės mokykloje sudedamają dalị. Mokinių, tèvų ir pedagogų bendradarbiavimas, darni veikla, progimnazijos mikroklimatas padeda siekti veiklos valdymo veiksmingumo, formuoti progimnazijos įvaizdị visuomenèje. Šie tyrimo duomenys atskleidžia kitų mokslininkų (Day, Sammons, 2014) minți, kad švietimo lyderių uždavinys - tobulinti ugdymo institucijų veiklą, siekti veiklos veiksmingumo, formuoti aiškią ịstaigos viziją ir veiklos kryptị.

Vadovo lyderystės požymị veiklos valdyme atskleide išryškẻjusios progimnazijos veiklos valdymo veiksmingumo priemonės: nuolatinio ịstaigos įsivertinimo ir ugdymo proceso dalyvių nuomonių tyrimų organizavimas, aktyvus dalyvavimas projektinejje veikloje, ugdymo bei veiklos planų rengimas ir jų vykdymo stebėsena, darbo bei ugdymo(si) sąlygų gerinimas, lèšų ì progimnaziją naujovèms ir inovacijoms diegti pritraukimas, veiklos valdymo kokybės gerinimas, mokytojų savišvietos bei lyderystės skatinimas. Šie interviu duomenys patvirtina ir kitu tyrimų rezultatus: veiksmingas mokyklos valdymas siejamas su veiklos vertinimo ir ịsivertinimo procesais (Everard ir kt., 2004); gerų darbo sąlygų užtikrinimas yra ne tik vadovo atsakomybė, bet ir veiks- 
mingos mokyklos veiklos garantija (Arman ir kt., 2016); švietimo įstaigoje svarbi tiek formalaus mokyklos vadovo, tiek ir mokytojų lyderyste (Saleem ir kt., 2020; Leffler, 2019). Apibendrinant galima teigti, kad tyrime dalyvavusių progimnazijų vadovai lyderystę veiklos valdymo procese supranta ne kaip individualų reiškinį, bet kaip mokyklos bendruomenès narių susitelkimą, siekiant lyderystės ir veiklos valdymo kokybės.

\section{Išvados}

Atlikus interviu su progimnazijų vadovais analizę, išryškèjo keli esminiai lyderystès veiklos valdymo procese požymiai. Visų pirma paties vadovo atsakomybės už mokyklos veiklos valdymą prisièmimas, administracijos atstovų, mokytojų ir mokinių tarybų, tėvų bei socialinių partnerių telkimas, siekiant veiksmingai valdyti veiklą. Vadovas bendruomenès narius ị mokyklos veiklos valdymą įtraukia organizuodamas teikiamų iniciatyvų aptarimą, apklausų duomenų analizę, diskusijas ir forumus, sudarydamas darbo grupes ir kt. İtraukimo formos gali būti ịvairios. Bendruomenès nariai vadovų skatinami patys ịsitraukti ị progimnazijos veiklos valdymą. Tai vyksta organizuojant renginius, derinant ugdymo ir veiklos planus, dalyvaujant ugdymo(si) kokybės užtikrinimo procese, projektinèje veikloje, skatinant mokinių savivaldą, kuri lemia pilietiškumą ir akademinius pasiekimus.

Vadovai minejjo, kokias sąlygas jie sudaro mokytojams dalyvauti veiklos valdymo ir kvalifikacijos tobulinimo procesuose, reikštis iniciatyvoms ir dalytis lyderystès patirtimis, puoselèti santykius, kitaip tariant, mokytojų lyderystei progimnazijoje įsitvirtinti.

Vadovų lyderystė reiškiasi ieškant veiksmingų veiklos valdymo sprendimų nuolat stebint ir vertinant pažangą bei pasiekimus, analizuojant ir reflektuojant veiklos tikslus bei rezultatus, puoselejant bendruomenès narių tarpusavio santykius, bendradarbiaujant, kuriant mikroklimatą ir kt. Veiksmingos progimnazijos veiklos valdymo priemonès yra nuolatinio ịstaigos ịsivertinimo ir ugdymo proceso dalyvių nuomonès tyrimų organizavimas, darbo bei ugdymo(si) sąlygų gerinimas, veiklos valdymo kokybės užtikrinimas, mokytojų savišvieta, projektinè veikla, inovacijų diegimas.

\section{Literatūra}

Arman, S. T., Darman, M. (2016). The effect of school supervisors competence and school principals competence on work motivation and performance. International Journal of Environmental \& Science Education, Vol. 11 (15), p. 7309-7317. Ebsco publishing.

Bagdonè, I. (2015). Šiuolaikinès mokyklos valdymas. Švietimo problemos analizė, Nr. 2(126), p. 1-12.

Bendrojo ugdymo mokyklu veiklos kokybè. (2015). Nacionalinès mokyklų vertinimo agentūros metinis pranešimas. Prieiga internete: http:/www.nmva.smm.lt/wp-content/uploads/2012/12/Metinis-pran e\%C5\%A1imas-maketas- 02.04.pdf

Bickmore, D. L. (2016). The middle grades principal: A research agenda. Middle School Review, Vol. 2(3), Article 4. Prieiga internete: https://files.eric.ed.gov/fulltext/EJ1154825.pdf

Bitinas, B., Rupšienė, L., Žydžiūnaitė, V. (2008). Kokybiniu tyrimu metodologija. Klaipèda: S. Jokužio leidyklaspaustuvè.

Bryman, A. (2017). Social research methods. Oxford: Oxford University Press.

Cibulskas, G., Žydžiunaitė, V. (2012). Lyderystès vystymosi mokykloje modelis. Vilnius: Lodvila.

Day, Ch., Sammons, P. (2014). Successful school leadership. Education Develpoment Trust. Prieiga internete: https://www.educationdevelopmenttrust.com/EducationDevelopmentTrust/files/a3/a359e571-7033-41c7-8fe79ba60730082e.pdf

Everard, K. B., Morris, G., Wilson, I. (2004). Effective school management. Prieiga internete: https://uk.sagepub.com/ en-gb/eur/effective-school-management/book226510\#

Flowers, P., Larkin, M., Smith, J. A. (2009). Interpretative Phenomenological Analysis: Theory, Method and Research. London: Sage.

Cheung, R., Reinhardt, T., Stone, E., Little, J. W. (2018). Defining teacher leadership: A framework. Prieiga internete: https://journals.sagepub.com/doi/full/10.1177/0031721718808263

Coughlin,A. M., Baird,L.(2013). PedagogicalLeadership [interaktyvus]. London Bridge Child Care Services\&Kawartha Child Care Services. Prieiga internete: http://edu.gov.on.ca/childcare/Baird_Coughlin.pdf

Creswell, J. W. (2012). Qualitative Inquiry and Research Design. Choosing Among Five Approaches. SAGE Publications. 
Haynes, N. M., Arafeh, S., McDaniels, C. (2014). Educational leadership: perspectives on preparation and practice. Prieiga internete: https://books.google.lt/books?hl=lt\&lr=\&id=ih8JBgAAQBAJ\&oi=fnd\&pg=PA $253 \& \mathrm{dq}=$ leadership + in + education \&ots=x-DfEATL0X\&sig=wMN1SwrGQKraCXtiLDnzLvb3E0\&redir_ esc $=\mathrm{y} \# \mathrm{v}=$ onepage $\& \mathrm{q}=$ leadership $\% 20 \mathrm{in} \% 20$ education $\& \mathrm{f}=$ false

Hargreaves, A., Fink, D. (2012). Sustainable leadership. Prieiga internete: https://scholar.google.lt/scholar?start=40\&q $=$ Leadership + competence+asa+factor $+\mathrm{in}+$ school+efficiency+boost\&hl=lt\&as sdt=0,5\&as_vis $=1$

Hesse-Biber, Sh. N., Leavy, P. (2011). The Practice of Qualitative research. SAGE Publication.

Yukl, G. (2012). Effective Leadership Behaviors: What We Know and What Questions Need More Attention? The Academy of Management Perspectives. Ebsco Publishing.

Kim, J., Youngs, P., Frank, K. (2017). Burnout contagion: Is it due to early career teachers' social networks or organizational exposure? Teaching and Teacher Education, No. 66, p. 250-260. Prieiga internete: https://doi.org/10.1016/j. tate.2017.04.017

Leffler, E. (2019). An Entrepreneurial Attitude: Implications for Teachers' Leadership Skills? Leadership and Policy in Schools. Published online: 08 Oct 2019. Prieiga internete: https://doi.org/10.1080/15700763.2019.1668021

Lietuvos Respublikos švietimo ịstatymas. (2011). Nr. 38-1804. Teisès akto redakcija ịsigalioja nuo 2020-01-01. Prieiga internete: http://www.infolex.lt/ta/54723:str41

Lietuvos Respublikos švietimo ir mokslo ministro įsakymas „Dèl geros mokyklos koncepcijos patvirtinimo“. (2015). Nr. V-1308. Vilnius. Prieiga internete: https://www.etar.lt/portal/lt/legalAct/f2f65120a7

Lotter, C., Yow, J. A., Leel, M., Zeis, J. G., Irvin, M. (2020). Rural teacher leadership in science and mathematics. School Science and Mathematics, Vol. 120, p. 29-44. Prieiga internete: https://onlinelibrary.wiley.com/doi/pdf/10.1111/ ssm. 12383

Marzano, R. J., Waters, T., McNulty, B. A. (2011). Veiksminga mokyklu lyderystè. Nuo mokslinių tyrimu iki rezultatų. Vilnius: Vilniaus pedagoginio universiteto leidykla.

McCray, C. R., Beachum, F. D. (2014). School Leadership in a Diverse Society: Helping Schools Prepare All Students for Success. Prieiga internete: http://ezproxy.biblioteka.ku.lt:3672/ehost/detail/detail?vid=6\&sid=2ca175f7-7a0a417e-bd2cbbfdc1ed7706\%40sessionmgr4005\&hid=4104\&bdata=JnNpdGU9ZWhvc3QtbGl2ZQ\%3d $\% 3 \mathrm{~d} \# \mathrm{db}=\mathrm{nle}$ bk\&AN $=688072$

Moustakas, C. (1994). Phenomenology research methods. Thousand Oaks, California: Sage Publications.

Navaitienė, J., Danilovienė, V. (2017). Mokytojų perdegimas darbe ir perfekcionizmas. Ugdymo psichologija: mokslo darbai, Nr. 28, p. 38-55. Prieiga internete: http://ugdymopsichologija.leu.lt/index.php/Ugdymopsichologija/article/ view/88/55\#

Navickaitė, J. (2012). Mokyklos vadovo lyderystė vykstančių švietimo pokyčių kontekste. Acta Paedagogica Vilnensia, No. 29, p. 35-46.

Northouse, P. G. (2016). Leadership: Theory and practice. Thousand Oaks, CA: Sage.

Progimnazijų ir pagrindinių mokyklu paskirtis ir vieta bendrojo ugdymo sistemoje. (2016). Parengè A. Gražytè. Švietimo problemos analize, Nr. 2 (145), p. 1-12. Prieiga internete: http://www.nmva.smm.lt/wp-content/uploads/2012/12/ progimnazijos.pdf

Rupšienè, L. (2007). Kokybinio tyrimo duomenu rinkimo metodologija. Klaipėda: KU leidykla.

Saleem, A., Aslam, S., Hong-biao, Y., Congman, R. (2020). Principal Leadership Styles and Teacher Job Performance: Viewpoint of Middle Management. Sustainability, Vol. 12(8), p. 1-15. Prieiga internete: https://www.researchgate. net/publication/341265125_Principal_Leadership_Styles_and_Teacher_Job_Performance_Viewpoint_of_Middle_Management

Storey, J. (ed.) (2016). Leadership in Organizations - Current issues and key trends. London: Routledge. Prieiga internete: http://oro.open.ac.uk/44224/1/Chapter\%202.\%20Changing\%20Theories\%20of\%20Leadership\%20.pdf

Skarbalienè, A. (2015). Lyderystè, autoritetas ir moralinès vertybės postmodernizmo kontekste. Logos, Nr. 83, p. $140-147$.

Skarbalienè, A. (2015a). Mokytojų lyderystė ir jos sąsajos su švietimo kokybe. Švietimo problemos analizè, Nr. 16 (140), p. 1-8. Prieiga internete: https://www.sac.smm.lt/wp-content/uploads/2016/01/4_naujausi1_Mokytoj\%C5\%B3-lyderyste.pdf

Sowell, M. (2018). It's What Principals Do: Influencing Teachers to Support Students. Eric, Vol. 23, p. 1-21. Prieiga internete: https://files.eric.ed.gov/fulltext/EJ1191666.pdf

Valuckienė, J., Balčiūnas, S., Katiliūtė, E., Simonaitienė, B., Stanikūnienė, B. (2015). Lyderyste mokymuisi: teorija ir praktika mokyklos kaitai. Prieiga internete: https:/www.sac.smm.lt/wp-content/uploads/2016/01/Lyderyste-mokymuisi_teorija-ir-praktika-mokyklos-kaitai.pdf

Wenner, J. A., Campbell, T. (2017). The Theoretical and Emipirical Basis of Teacher Leadership: A Review of the Literature. Review of Educational Research, Vol. 87(1), p. 134-171. Prieiga internete: https://journals.sagepub.com/ doi/10.3102/0034654316653478

Žydžiūnaitè, V., Sabaliauskas, S. (2017). Kokybiniai tyrimai. Principai ir metodai. Vilnius: Vaga. 


\title{
THE LEADERSHIP OF PROGYMNASIUM HEADS IN THE MANAGEMENT OF SCHOOL ACTIVITIES
}

\author{
Lilia Žukauskiené, Aurelija MacijauskienĖ \\ Klaipèda University (Lithuania)
}

\section{Summary}

Leadership has become a priority area in education policy; therefore, since Lithuania entered a new stage of development in order to establish itself in the international area and learn to cooperate and compete in a global world, discussions of necessary improvements and the reorganisation of the education system have been taking place increasingly frequently. One of the changes in the 21 st-century Lithuanian education system was the implementation of a new school network structure, and the introduction of a new type of school, the progymnasium, of which the main purpose was to implement a basic curriculum (or part of one) and prepare students (forms 1 to 8) for further education (Law on Education of the Republic of Lithuania, 2011, Article 41, Paragraph 2. The legislation entered into force on 01-01-2020). A progymnasium without leadership in shaping a new culture of educational management is currently hard to imagine.

The aim of the research was to show the essential traits of the leadership activities of progymnasium heads. The research was based on a strategy of qualitative research, i.e. phenomenology, according to which the nature and ways of human experience are revealed by studying phenomena. In phenomenology, philosophical assumptions are based on the study of living experience, the view that these experiences are conscious, and descriptions of these experiences were not created solely through explanations or analysis (Moustakas, 1994). Phenomenology made sense whenever a researcher expected to understand a phenomenon in order to develop best practice (Creswell, 2012).

The participants in the survey were five heads of progymnasiums in the western region of Lithuania (Klaipėda, Šilutè, Kretinga and Tauragè). They were selected for participation in the research through target criterion-based selection.

Research results. Interviews with the heads of progymnasiums revealed an essential trait of the head's leadership in activity management: the leader was the first to assume responsibility for the management of school activities, and simultaneously he brought together other members of the community, representatives of the administration, teacher and student councils, parents and social stakeholders.

The heads of the progymnasiums expressed leadership by involving community members in activity management in various forms. Meetings of teacher and student councils, discussions of initiatives proposed by community members (parents or educators), the analysis of data from anonymous surveys carried out by teachers, discussions and forums, and the mobilisation of working groups, promoted an atmosphere of mutual trust and activated students and teachers.

The interviews helped to reveal another characteristic, the involvement of community members in the management of progymnasium activities. In order to achieve the common goals of the progymnasium, together with other members of the community, the heads organised various events at the school and outside it, coordinated educational and action plans, participated in the process of change of educational quality, and engaged in management rallies and project activities.

By creating the conditions for teacher participation in the management of progymnasium activities and continuous professional development, supporting teacher initiatives, sharing leadership experience with them, and motivating teachers for activity by word of mouth, support and material incentives, the heads strove for coherence in relations between the administration and the teachers.

The head's leadership in activity management was manifested when the search for effective activity management solutions in a progymnasium involved the continuous monitoring of students' learning progress, the formal and informal assessment of progress and achievements, the promotion of a clearly defined achie- 
vement assessment system, internal checking of the evaluation of activity management, and the analysis and reflection of the goals and results of activities.

The data from the interviews highlighted another feature of the head's leadership in activity management, the desire to continuously improve activity management. The heads identified the development of sustainable relationships between members of the progymnasium community as a significant component of leadership at school. The cooperation between students, parents and teachers, coherent actions, and the micro-climate of the progymnasium, contributed to making the management of activities more effective, and to forming the public image of the progymnasium.

The head's leadership in activity management was shown by measures making the management of progymnasium activities more effective, such as: the regular organisation of institutional self-assessment and opinion surveys of participants in the educational process, participation in project activities, the development of education and action plans and the monitoring of their implementation, the improvement of work and educational conditions, attracting funding for new ideas and innovations, development in the area of the quality of activity management, and encouraging teachers to pursue self-education and leadership.

The heads of the respondent progymnasiums understood leadership in activity management not as an individual phenomenon, but as focusing the members of the school community on leadership and the quality of activity management.

KEYWORDS: progymnasium, manager, leadership competence, activity management.

JEL CODES: I12, I21; I31.

Gauta: 2020-08-16

Priimta: 2020-09-14

Pasirašyta spaudai: 2020-10-10 